\title{
Bacteria enhanced lignocellulosic activated carbon for biofiltration of bisphenols in water
}

\author{
Hemen Sarma ${ }^{1,2}$ (1) $\cdot$ Wen-Yee Lee ${ }^{2}$ \\ Received: 20 November 2017 / Accepted: 4 May 2018 / Published online: 28 May 2018 \\ (C) Springer-Verlag GmbH Germany, part of Springer Nature 2018
}

\begin{abstract}
There are eight bisphenol analogues being identified and characterized; among them, bisphenol A (BPA) is on the priority list on the basis of its higher level of uses, occurrence, and toxicity. The endocrine system interfered by BPA has been inventoried as it has the same function as the natural hormone $17 \beta$-estradiol and binds mainly to the estrogen receptor (ER) to exhibit estrogenic activities. The BPA concentration in surface waters (14-1390 ng/L) in many parts of the world, such as Japan, Korea, China, and India, was also a significant concern. Research efforts are focusing on restricting BPA consumption as well as removing BPA in our environment especially in drinking water. Current opinion is that lignocellulosic activated carbon stimulated with BPAdegrading bacteria could have the potential to provide solution for recent challenges faced by water utilities arising from BPA contamination in water. This technology has some new trends in the low-cost biofiltration process for removing BPA. This review is to provide in-depth discussion on the fate of BPA in our ecosystem and underlines methods to enhance the efficacy of activated carbon in the presence of BPA-degrading bacteria in the biofiltration process.
\end{abstract}

\section{Introduction}

Bisphenols (BPs) are a cluster of emerging contaminants that currently threaten the global ecosystem due to their higher level of toxicity as an endocrine disruptor (Tsai 2006; Vandenberg et al. 2009; Rogers et al. 2013). There are eight bisphenol analogues being identified and characterized: bisphenol A (BPA), bisphenol S (BPS), bisphenol F (BPF), bisphenol B (BPB), bisphenol P (BPP), bisphenol Z (BPZ), bisphenol AF (BPAF), and bisphenol AP (BPAP) (Fig. 1), and among those, BPA draws the most attention because it is most commonly used for production of polycarbonate (PC) plastics and epoxy resins. The production of BPA-based plastics for commercial use was initiated by Bayer Plastics (Germany) and General Electric (USA) in 1955 (Krimm et al. 1962; Henno and Pettis 1966), and the usage of PC plastics has

Responsible editor: Philippe Garrigues

Hemen Sarma

hemens02@yahoo.co.in

1 Department of Botany, N.N. Saikia College, Titabar, Assam 785630, India

2 Department of Chemistry and Biochemistry, University of Texas at El Paso, 500 W. University Ave, El Paso, TX 79968, USA surpassed 260 million tons per year globally (Barnes et al. 2009). BPA is used as a monomer in making PC plastics and epoxy resins in electronic equipment, automobiles, construction glazing, sports safety equipment, laboratory and medical devices, tableware, reusable bottles (e.g., baby bottles), and food storage containers. By 2003, the global production of BPA was 3.2 million metric tons (Tsai 2006). The demand of BPA has been growing steadily over the past few decades in Asian countries, especially South Korea, China, and Japan, accounting for a major share of BPA production globally (Huang et al. 2012) due to the increase of population. As a result, BPA has been detected in both terrestrial and aquatic ecosystems (Staples et al. 1998; USEPA, 2010). Take the populated country, India, as an example. Although it has no BPA production plants, the indiscriminate use of plastics and lack of government legislation are causing this country to badly suffer from the rising BPA level in the aquatic ecosystem (Mahamuni and Shrinithivihahshini 2017). The presence of BPA, BPS, and BPF has been reported throughout the river ecosystem (Yamazaki et al. 2015) and sediments (Wu et al. 2013) and even in drinking water treatment plant waters (Stackelberg et al. 2004). The number of publications on such topic has greatly increased from fewer than 400 in 2001 to more than 2000 in 2017 (Fig. 2a), and it has highlighted the significant attention of BP in our water systems. 
Fig. 1 Chemical structure of bisphenol analogues (see Yamazaki et al. 2015)<smiles>CC(C)(c1ccc(O)cc1)c1ccc(O)cc1</smiles>

Bisphenol A (BPA)<smiles>O=S(=O)(c1ccc(O)cc1)c1ccc(O)cc1</smiles>

Bisphenol S (BPS)<smiles>OC1=CC=C(Cc2ccc(O)cc2)CC1</smiles>

Bisphenol F (BPF)<smiles>CCC(C)(c1ccc(O)cc1)c1ccc(C(C)(C)c2ccc(C(C)(C)c3ccc(O)cc3)cc2)cc1</smiles>

Bisphenol B (BPB)
Bisphenol Z (BPZ)<smiles>Oc1ccc(C(c2ccc(O)cc2)(C(F)(F)F)C(F)(F)F)cc1</smiles>

Bisphenol AF (BPAF)<smiles>CC(c1ccccc1)(c1ccc(O)cc1)c1ccc(O)cc1</smiles>

Bisphenol AP (BPAP)
Furthermore, the extensive use of PC plastics as food containers for storage or food processing increases the exposure of humans to BPA through oral ingestion. BPA and other BP analogues were identified in the breast milk, egg, etc. (Shao et al. 2007). The extensive use of epoxy resins and PC plastics from bisphenol residue left in food stuff, water, sediment, and indoor dust (Liao et al. 2012; Lee et al. 2013; Wu et al. 2013; Zhang et al. 2013; Selvaraj et al. 2014; Colin et al. 2014; Lee et al. 2015) causes detrimental effects on living organisms. BPA leaches from polycarbonate bottles/plastics into liquid (coffee, tea, and soft drinks). The amount of BPA leached mainly depends on the temperature, not on the age of the container; high-temperature liquids have the potential to leach more BPA. The heat and hydrolysis, such as pasteurization, sterilization, microwave heat treatment prior to serving, and washing of the plastic containers, result in increased leaching of the BPA (vom Saal and Hughes 2005).
Fig. 2 a A continuous increase in publications featuring BPA, BPS, and BPF from 2001 to 2017 (source: www.sciencedirect.com; search parameters used (bisphenols, water, breast cancer, sperm sterility, cardiovascular diseases, and diabetes). b A continuous increase in publications related to activated carbon, BPA-degrading bacteria, and BPA bioremediation from 2001 to 2017 (source: www. sciencedirect.com)
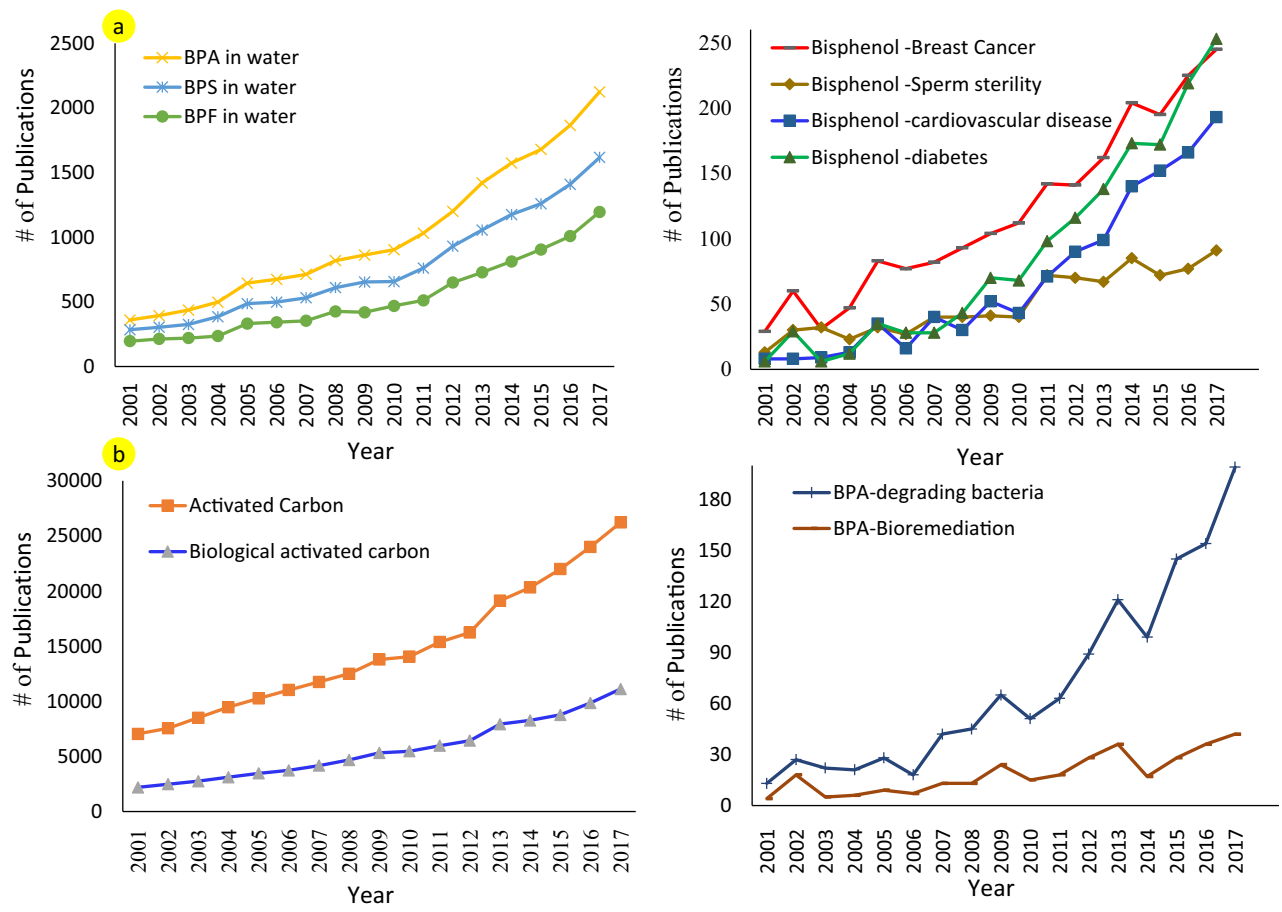
The potential endocrine-disrupting effects of BPA were first recognized in 1997 in an animal model (Steinmetz et al. 1997; vom Saal et al. 1997). Having affected more than $5 \%$ of the US population, endocrine disorders have proven to be a significant public health concern. Disorders like diabetes mellitus, obesity, metabolic disorders, osteoporosis, osteopenia, erectile dysfunction in males, and thyroiditis are found to be more prevalent among the US population (Golden et al. 2009). A recent search conducted in ScienceDirect continues to see an increase in publication featuring the BPA-breast cancer, BPA-sperm sterility, BPA-cardiovascular diseases, and BPA-diabetes; a total of 782 articles have been indexed in Web of Science starting only 56 in 2001 (Fig. 2b).

Even though BPA has been observed at concentrations ranging from nanograms per liter (ng/L) to micrograms per liter $(\mathrm{mg} / \mathrm{L})$ in drinking water, the long-term consequent exposure of a living organism to this endocrinedisrupting compound cannot be ignored considering its significant negative impact (Golden et al. 2009). As a result, the recent water treatment technologies have been emphasized in treating BPA and other contaminants of emerging concerns (CECs) including advanced oxidation processes (Rosario-Ortiz et al. 2010), ozonation (Wert et al. 2007), and activated carbon (AC) (Kennedy et al. 2015). It was well established that activated carbon significantly reduces dissolved organic carbon (DOC) in the treated water by binding the organic carbon compounds to absorption sites. The efficacy of dissolved organic matter removal by granular activated carbon (GAC) filtration has been proved to produce highly stable water $(\mathrm{TOC}=0.1$ to $1.2 \mathrm{mg} \mathrm{L}^{-1}$ ) (Chandy and Angles 2004). The application of biologically enhanced activated carbon (BAC) has a potential to be used in the removal of BPA from drinking water in the future. The organic precursors rich in carbonplant residues, lignocellulosic material, agriculture waste, and desired bacterial strains - can be used as potential materials of making BAC (Yamanaka et al. 2008).

The application of carbon in human civilization dates back to the age of Hippocrates (around $400 \mathrm{BCE}$ ). Evidence shows that carbon was used in this time period to eliminate bad odor and taste and improve water quality and/or to prevent infectious diseases. Water was filtered with a wood char prior to consumption (Inagaki and Tascon 2006). With the historical use, AC is known to remove many of the micropollutants (aromatic compounds, antibiotics, detergents, soluble dyes, chlorinated solvents, phenols, and hydroxyl derivatives) and emerging contaminants (including pesticides and endocrine disruptor compounds including bisphenol A) from water, therefore gaining popularity in both more economically developed countries and less economically developed countries (Inagaki and Tascon 2006). But after continuous running for 5 months or 14,600 bed volumes were filtered, the absorbability of activated carbon dropped significantly (Zhang et al. 2010). Interestingly, the removal rate in a BAC filter increases the lifespan of the carbon by at least 10 years. This is because the polysaccharides produced by bacteria attaching to the activated carbon grains adsorb or degrade the organic contaminants and their pores remain open for a longer period of time (Zhang et al. 2010). Therefore, BAC has more benefits when they are sustained for longer periods of time. Furthermore, when dissolved organics are removed by bacterial catabolic activities, the biological filter beds become active for a longer period (Yamanaka et al. 2008). The scientific production in carbon materials during the last 20 years has been very active and the current demand of activated carbon (liquid phase) accounts for more than $70 \%$ (Rodríguez-Reinoso et al. 2009), and most of it is used for the treatment of drinking water. A recent search conducted in ScienceDirect continues to see an increase in publication featuring the activated carbon and biologically activated carbon with a total of 37,357 articles which have been indexed in Web of Science starting at 9234 in 2001 (Fig. 2b).

This review reiterates the fate of BPA in our ecosystem, environmental concern, and mitigation option from drinking water. It also underlines methods to enhance the efficacy of activated carbon in the presence of BPA-degrading bacteria in the biofiltration process - these approaches have been carefully considered in these articles in order to meaningfully apply BPA-degrading bacteria for the welfare of biodiversity.

\section{Residue and recycling of BPs in the ecosystem}

Bisphenol analogues, especially BPA, are infiltrated into the ecosystem not primarily by dumping of BPAcontaining plastics but by having some other sources that elevated the level of BPA in the environment (Fig. 3). The chemical waste of industrial origin is also a significant contributor of BPs. In Japan, cases of extremely high BPA were detected in the effluents (up to $370 \mu \mathrm{g} / \mathrm{L}$ ) in paper recycling plants (Fukazawa et al. 2001). This can be used as substantial evidence proving the significant impact of industrial chemicals as a contributor of BPs. The presence of BPA was also spotted in underground water in a significant amount range of $0.05-0.20 \mu \mathrm{g} / \mathrm{L}$ (GonzalezCasado et al. 1998). The BPA in surface waters (14$1390 \mathrm{ng} / \mathrm{L})$ of some Asian countries such as Japan, Korea, China, and India (Table 1) was recently detected and found to be toxic for organisms (Yamazaki et al. 2015). These results suggested that surface waters in several Southeast Asian countries are not safe for drinking without treatment. Similarly, high levels of BPF such as 

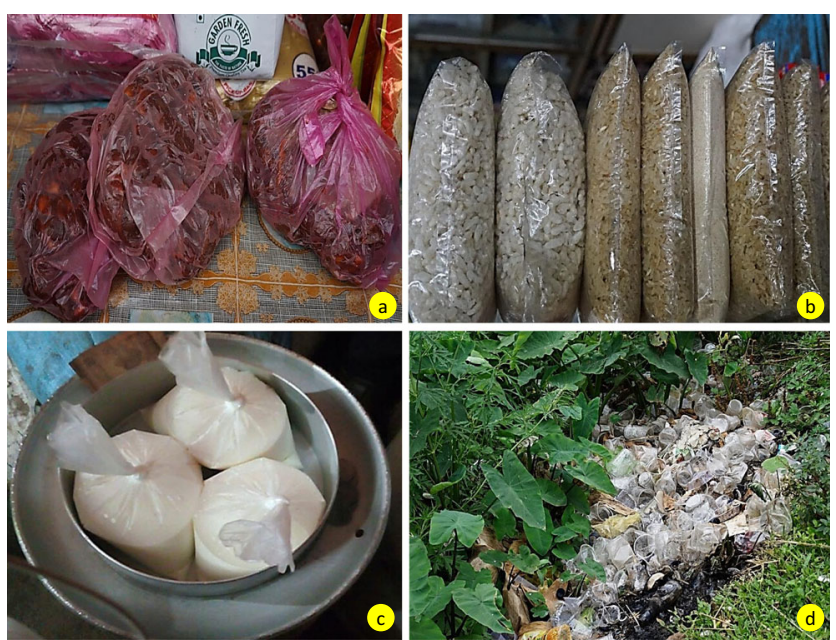

Fig. 3 The use of plastic for business (selling tamarind pickle (a), processed rice (b), and milk (c) in plastic packets in the street in north east India) and unscientific disposal of used plastic water glass (d)

that found in the Tamagawa River in Japan with concentration levels of $2850 \mathrm{ng} / \mathrm{L}$ show that consuming water from such sources is ill advised (Yamazaki et al. 2015). BPA is also present in soil/sediments and air other than plastic and metal products (Tables 2 and 3 ).

Despite the fact that several studies are available to establish the toxicity of BPA even at lower concentrations, the inconsistency of such studies provides challenges for preparing regulatory policies against BP usage in plastics by government agencies. Considering that BPA is a potential endocrine-disrupting compound (EDC), about 40 countries have adopted prohibitory policies on BPA with regard to food and its contact with plastics. Nonetheless, the highest populated country of the world, India, with a large number of plastic users, still does not have any policies for regulating BPA usage.

\section{BP-biodiversity interactions}

Currently, a strong interest in bisphenols in their significant adverse effects on millions of life forms in the biosphere has taken into consideration as an emerging research area worldwide. This group of chemicals disrupts the endocrine system of an organism (Fig. 4). The endocrine system is vital for body physiology as it is made up of certain glands that secrete hormones that help normal metabolic function and biochemical reactions (Beausoleil et al. 2018 ). The glands that secrete hormones regulate all biochemical reactions in different life stages. BPA can mimic the body's physiology by changing hormone levels that not only disrupt the functions of mitotic cells by acting as an estrogen agonist (Wozniak et al. 2005) but can also affect significant meiotic cells as seen in human fetal development (Sharma et al. 2018). The negative impacts of BPA exposure on the reproductive functions of many of the wildlife both vertebrae and invertebrate including aquatic and terrestrial have become a matter of concern (Jörg et al. 2009). Consequently, many investigations also keep data on the
Table 1 The concentrations of BPA in different rivers across the world

\begin{tabular}{llll}
\hline Country & River & Concentrations $(\mathrm{ng} / \mathrm{L})$ & Reference \\
\hline USA & Canals River & $1.9-158$ & Li and Li 2004 \\
& Bayou River & $9-44$ & Boyd et al. 2004 \\
Germany & Elbe River & $8.9-776$ & Stachel et al. 2003 \\
& Southwest River & $50-272$ & Bolz et al. 2001 \\
UK & Sussex River & $<5.3-24$ & Liu et al. 2004 \\
Spain & Granada River & $52.0-219$ & Gonzalez-Casado et al. 1998 \\
Taiwan & South Taiwan River & $59-228$ & Lin 2001 \\
Japan & Edogawa River & 14 & Yamazaki et al. 2015 \\
& Arakawa River & 30 & \\
& Tamagawa River & 48 & \\
Korea & Tokyo Bay & 325 & Yamazaki et al. 2015 \\
& Han River & 141 & \\
& Nakdong River & 40 & Yamazaki et al. 2015 \\
China & Yeongsan River & 136 & \\
India & Pearl River & 73 & Yamazaki et al. 2015 \\
& West River & 43 & \\
& Cooum River & 359 & \\
\hline
\end{tabular}


Table 2 BPA levels in soil and sediment found around the world

\begin{tabular}{llll}
\hline Country & Site & Concentrations (ng/L) & Reference \\
\hline USA & $\begin{array}{l}\text { Cherry Creek near Garland Park, Denver, } \\
\text { Colorado } \\
\text { Massachusetts Bay about 50 km south } \\
\quad \text { from the central part of the city of }\end{array}$ & $40-800$ & Burkhardt et al. 2005 \\
& $\quad$ Boston & & Stuart et al. 2005 \\
& Elbe River sediments & $7-1630$ & \\
Germany & Baden-Wurttemberg Riverine sediments & $0.5-15$ & Stachel et al. 2005 \\
& River Ouse sediment & $3.4-9$ & Bolz et al. 2001 \\
Taiwan & Southern Taiwan River sediments & $329-10,500$ & Liu et al. 2004b \\
Japan & Tokyo Bay surface sediments & $0.11-48.0$ & Lin 2001 \\
Korea & Masan Bay sediments & $2.70-50.3$ & Hashimoto et al. 2005 \\
& Ulsan Bay & $1.0-53.5$ & Khim et al. 1999 \\
China & Beijing-Wenyu River sediments & $0.6-59.6$ & Khim et al. 2001 \\
\hline
\end{tabular}

endocrine-disrupting action of BPA (Ho et al. 2006; Yu et al. 2015a; Belcher et al. 2012).

It was estimated that daily exposure to BPA at $50 \mathrm{mg} / \mathrm{kg}$ body weight significantly interferes with the developmental process and produces long-lasting effects on the structure and function of the brain (Kumar and Thakur 2017). Furthermore, anxietyand depression-like behavior in mammals could be the result of the exposure of BPA (Harley et al. 2013; Heredia et al. 2016). BPA has the same function as the natural hormone $17 \beta$-estradiol and binds mainly to the estrogen receptor (ER) to exhibit estrogenic activities (Quesada et al. 2002; Matsushima et al. 2007). Some of the chemicals such as bisphenol F (BPF) and bisphenol $\mathrm{S}$ (BPS) are generally used as alternatives in consumer products and labeled as "BPA-free," and currently 20 chemicals are suggested as a BPA alternative (Rochester and Bolden 2015).

The current research ascertained that exposure to BPA is likely to be the precursors of breast cancer (European Food Safety Authority (EFSA) 2010) and to reduce sperm count and may be linked to obesity by stimulating fat cell activity. In addition, exposure to BPA has been associated with chronic disease conditions in humans and animal models such as cardiovascular disease and diabetes and is a serum marker of liver disease (Lang et al. 2008). Although vitamin C (an antioxidant) can reduce DNA damage, it has been shown that BPA can cause oxidative stress on the human embryo liver L-02 cells by damaging DNA (Zhang et al. 2005). Many animal studies also showed that BPA exposure decreases sperm production (Qiu et al. 2013), increases the stillbirth rate (Wang et al. 2005), affects embryonic development (Pei et al. 2003), and decreases the viability of mesencephalic neuronal cells (Lin et al. 2006). In the latest research by Li et al. (2010), the study reported that BPA-exposed workers had consistently higher risk of male sexual dysfunction across all domains of male sexual function than the unexposed workers.

In summary, BPs can be viewed as a cluster of emerging contaminants that can infiltrate the environment at potentially hazardous levels. Their existence can be detected in both aquatic and terrestrial food chains, where millions of lives are exposed. The ubiquitous nature of BPA in these food chains that affects the endocrine system of humans and other life forms makes it to be considered a man-made silent killer of modern society. Therefore, appropriate action should be taken in effort to mitigate the negative effects of BPA exposure.

\section{Inoculation of BPA-degrading bacteria in activated carbon: prospective challenge in biofiltration}

In recent years, research focuses on the removal of BPA from the environment using BPA-degrading bacteria as it is the most ecofriendly and potentially effective. Although these
Table 3 BPA levels in ambient air found around the world

\begin{tabular}{llll}
\hline Country & Site & Concentrations $\left(\mathrm{pg} / \mathrm{m}^{3}\right)$ & Reference \\
\hline USA & North Carolina & $100-2500$ & Wilson et al. 2001 \\
& Albany, New York, USA & 790 & Xue et al. 2016 \\
Germany & NE Bavaria, Germany rural site & $5-15$ & Berkner et al. 2004 \\
India & Chennai & $200-17,400$ & Fu and Kawamura 2010 \\
Japan & Sapporo urban site & $70-930$ & Fu and Kawamura 2010 \\
China & Beijing & $380-1260$ & Fu and Kawamura 2010 \\
\hline
\end{tabular}




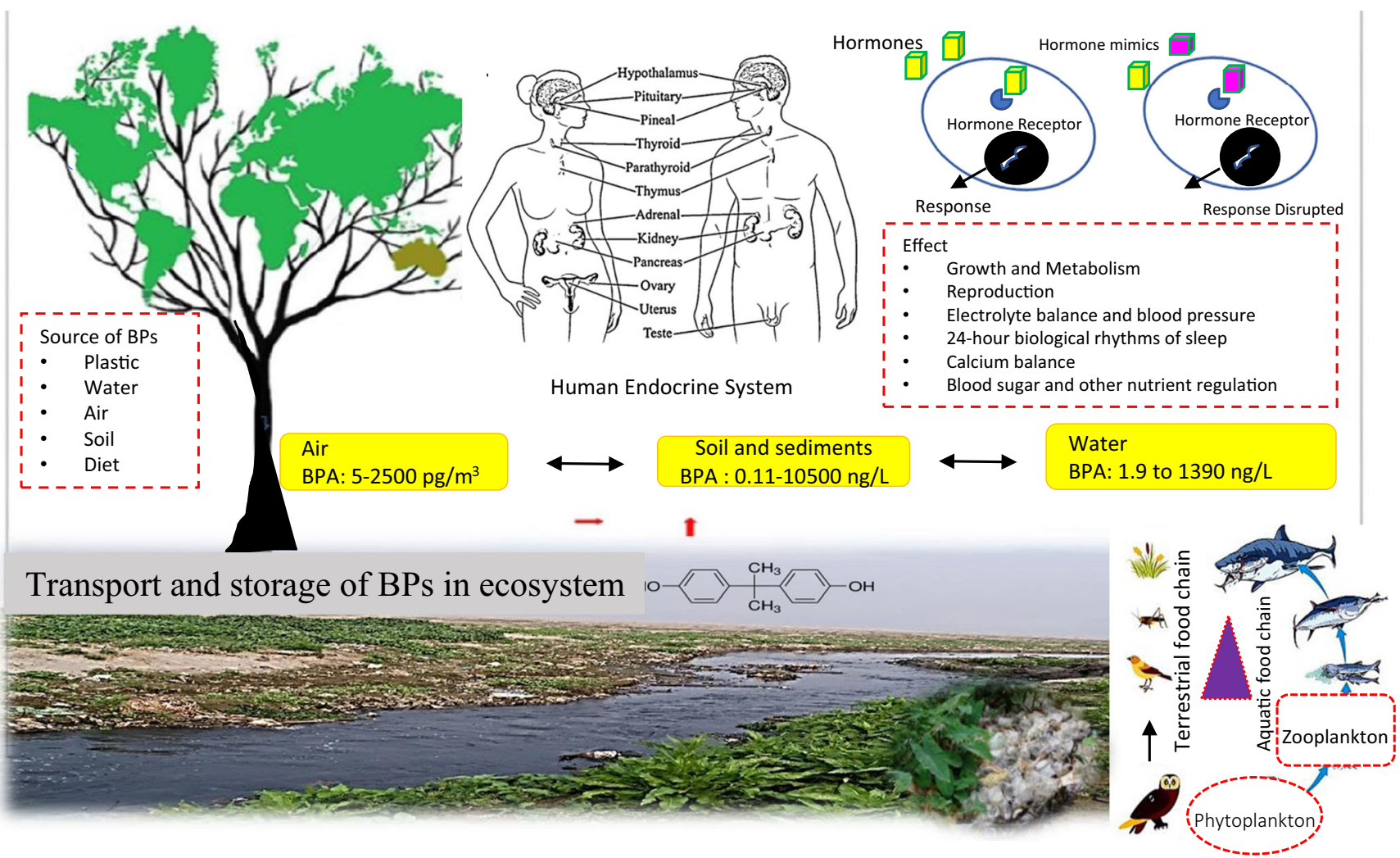

Fig. 4 BPA infiltration in the terrestrial and aquatic food chain originated from PC plastics across the world. The BPA concentration has significantly increased (2001-2017). The various sources of bisphenols

BPA-degrading bacteria are not widely used in the biofiltration process, they could be a good tool for removing BPA from various water sources. Biofiltration of polluted fluids by microorganisms has a potential benefit of biological activity (catabolism) which helps the removal process of organic contaminants (Cohen 2001). Current emphasis is on the biofiltration process to reduce the lifetime of organic pollutant in water environments as it is a low-priced option. Biofiltration is distinguished from a formal biowaste treatment technique by the fact that there is a partition within the microorganisms and the treated hazardous fluid. In biofiltration, the microbes are fixed and immobilized to the bedding material (e.g., activated carbon), while the treated fluid is migrant (i.e., it flows through the filter). There are certain methods that have been outlined for artificial immobilization of microorganisms to a support material (Cohen 2001). Research on biofiltration enhanced our capacity building towards petrochemical wastewater (Xie et al. 2009), sulfur compounds (Ramírez et al. 2011), methanol (Ramirez-Lopez et al. 2010), formaldehyde (Xie et al. 2009, 2010), and xylene (Singh et al. 2017). Unfortunately, evidence dealing with BPA water biofiltration is limited, although numerous fast BPA-degrading bacteria were isolated from soils, sludge, river, seawater, and even food sample (Table 4). The bacterial strains adopted in BPA-a sole carbon source-comprises Sphingomonas sp., with a hormone-receptor response mechanism and their effects on the endocrine system in long-term exposure

Pseudomonas sp., Achromobacter sp., Novosphingobium sp., Nitrosomonas sp., Serratia sp., Bordetella sp., Alcaligenes sp., Pandoraea sp., Klebsiella sp., and Cupriavidus sp. and gram-positive strains Streptomyces sp. and Bacillus sp. (Zhang et al. 2007; Kang and Kondo 2002). Considering the BPA-degrading potential, the strains are also useful for the conditioning of lignocellulosic AC; the combination of both could be a great prospect in the biofiltration process for the removal of organic micropollutants including BPA (Fig. 5). However, there are many BPA-degrading bacteria in the environment, and their BPA degradation abilities are strongly different with the strain specificity (Table 5).

$\mathrm{AC}$ is a state-of-the-art adsorbent broadly used for water purification for the removal of dissolved organics, CEC, and other micropollutants from drinking water including mycotoxins produced naturally in water (MorenoCastilla 2004; Quinlivan et al. 2005). The efficacy of many activated carbons depends primarily on the surface area, the pore structure (Moreno-Castilla 2004), and the quality of the raw materials used for their production. In the water treatment process, there are two types of $\mathrm{AC}$ usually used such as GAC and powdered activated carbon (PAC). Activated carbon has an internal porous structure (consisting of pores having diverse size distribution) which basically determines its ability to purify the water. However, 


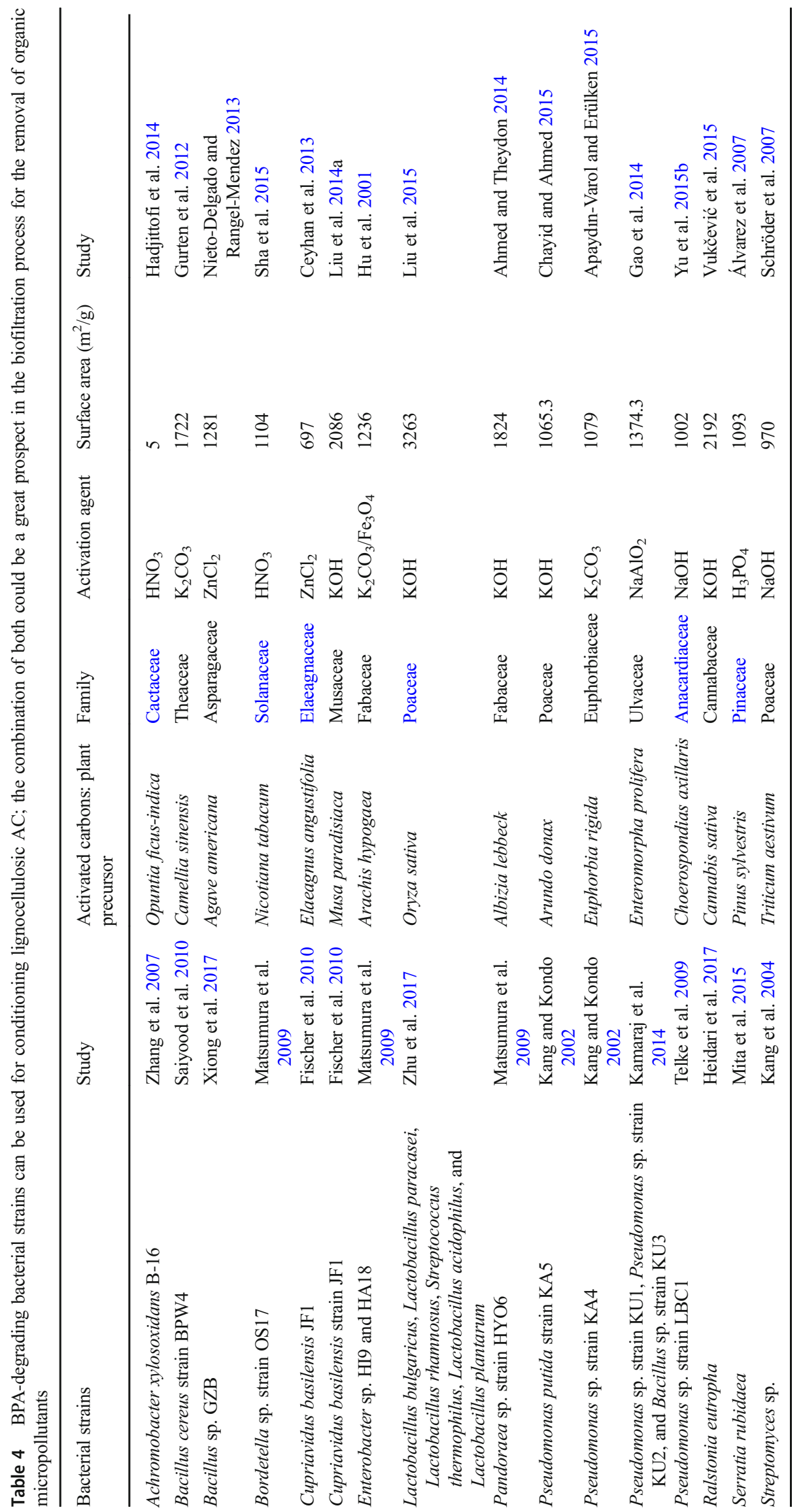


Fig. 5 Schematic representation of the biofiltration setup. (1) BP water and BP-degrading bacterial reservoir (incubation tank), (2) granular activated carbon filter bed, (3) clean water, and (4) UV sanitization unit

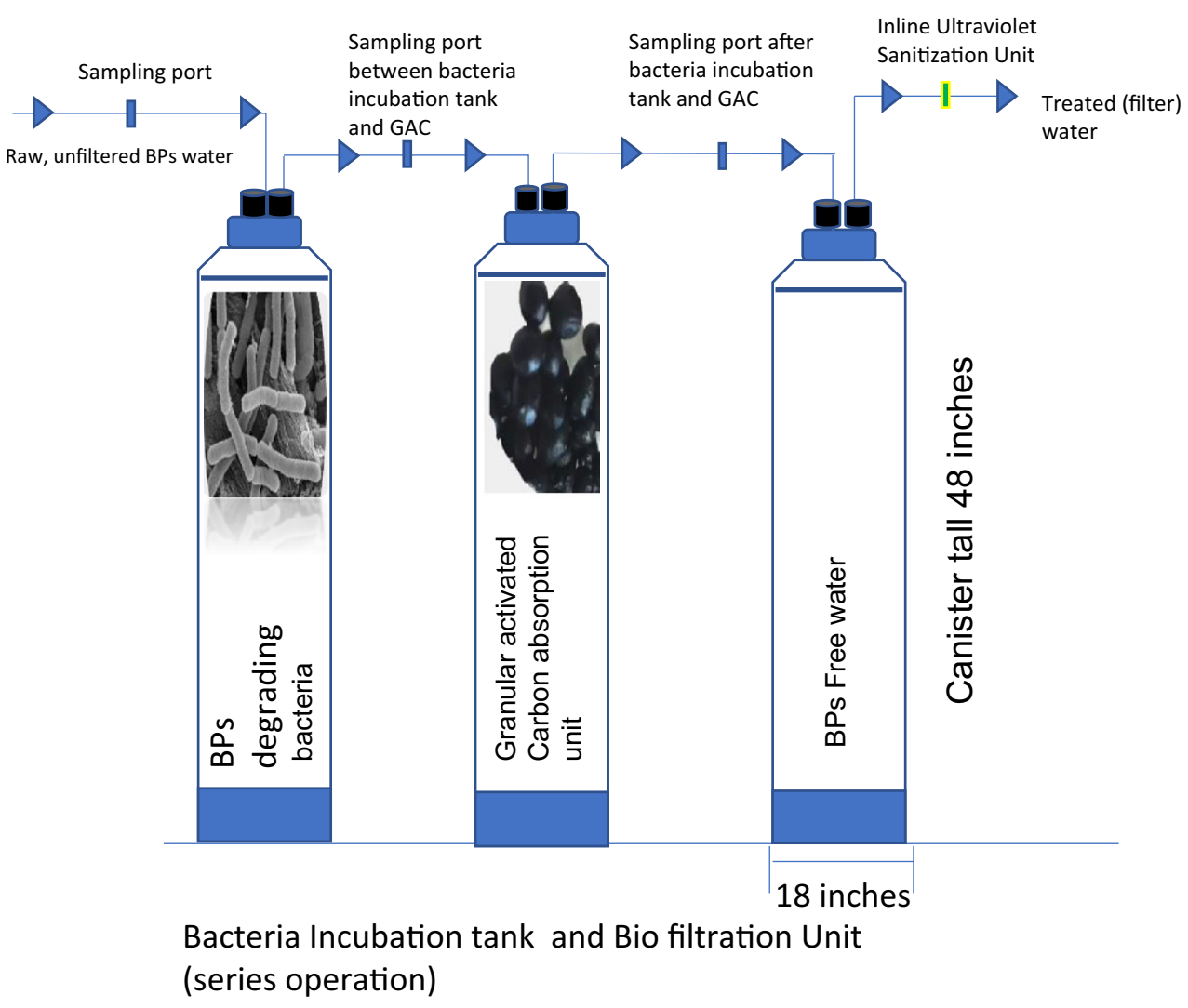

the efficacy of $\mathrm{AC}$ has been compromised by several issues. The major constraint relates to the decrease in the adsorption capacity of GAC over time due to saturation of available adsorption sites (Simpson 2008). After decades of intense research concerning the use of $\mathrm{AC}$ in water purification, it was confirmed that the reduction in efficacy of $\mathrm{AC}$ was because of competition for the absorption sites between dissolved organic carbon and pollutants as they form complexes with $\mathrm{AC}$ and alter its physicochemical properties (Quinlivan et al. 2005). Thus, activated carbons need to be replaced regularly, and therefore, long-term use of AC is critical.
However, the lifetime of AC could be extended by bioaugmentation of some potential microbes that degrade organic compounds and contaminants and maintain activity in the internal pores of AC.

As mentioned previously, bacteria are typically developed and proliferated in activated carbon beds which degrade the fraction of organics by utilizing them as their carbon source, thus being responsible for the net removal of contaminants. The bacteriamediated activated carbon removal of contaminants improved our understanding and helped our proposal for advanced and fast removal methods to improve performance of the water treatment

Table 5 The prospective BPA-degrading strains of the genus Sphingomonas

\begin{tabular}{|c|c|c|}
\hline Strains/consortia & Major observation & Study \\
\hline Sphingomonas sp. strain MV1 & $\begin{array}{l}\text { This strain completely degraded } 10 \mathrm{~g} \mathrm{~L}^{-1} \text { BPA within } \\
4 \text { days. The cell densities were recorded as }>10^{10} \mathrm{ml}^{-1}\end{array}$ & Lobos et al. 1992 \\
\hline Sphingomonas bisphenolicum strain AO1 & $\begin{array}{l}\text { Strain AO1 completely degraded BPA at } 115 \mathrm{mg} \mathrm{L}^{-1} \text { in } \\
6 \mathrm{~h} \text {, when cultivated in L-BPA medium at } 30^{\circ} \mathrm{C}\end{array}$ & Sasaki et al. 2005 \\
\hline $\begin{array}{l}\text { Sphingomonas sp. strain BP-7 and Pseudomonas sp. } \\
\text { strain BP-14 }\end{array}$ & $\begin{array}{l}\text { A mixed culture of Sphingomonas sp. strain BP-7 and } \\
\text { Pseudomonas sp. strain BP-14 showed complete deg- } \\
\text { radation of } 100 \mathrm{mg} \mathrm{L}^{-1} \text { BPA within } 7 \text { days }\end{array}$ & Sakai et al. 2007 \\
\hline $\begin{array}{l}\text { Sphingomonas sp. strain BP-7 and Sphingomonas } \\
\text { yanoikuyae strain BP-11R }\end{array}$ & $\begin{array}{l}\text { These consortia efficiently degraded } 300 \mathrm{mg} \mathrm{L}^{-1} \mathrm{BPA} \text { in } \\
\text { the presence of } \mathrm{AC} \text {, suggesting that an efficient system } \\
\text { for BPA removal can be constructed by introducing } \\
\text { BPA-degrading bacteria into an AC treatment system }\end{array}$ & Yamanaka et al. 2008 \\
\hline Sphingomonas sp. strains SO11, SO1a, and SO4a & $\begin{array}{l}\text { All the three strains completely degraded } 115 \mathrm{mg} \mathrm{L}^{-1} \\
\text { BPA within } 15 \mathrm{~h}\end{array}$ & Matsumura et al. 2009 \\
\hline
\end{tabular}


process. These processes are economically feasible and have been implemented in many large water treatment plants worldwide for other contaminants, excluding BPA. The microbial activity can enhance the absorption capacity of AC for nonbiodegradable or slowly biodegradable compounds by eliminating substances that would otherwise compete for absorption sites. Bioaugmentation of bacteria can create a bioregeneration effect of $\mathrm{AC}$ and enhance their lives for longer periods of time. However, the empty bed contact time is the most important parameter for the removal of biodegradable organic matter.

The bacteria colonize the rough porous surface of the $\mathrm{AC}$ and catabolize organic matters present on the surface as a source of energy. This biostimulated AC transformed to $\mathrm{BAC}$, and eventually, bacteria filled the pores and surfaces of the AC with biomass or "biofilm" (Quintelas et al. 2010; Rattier et al. 2012). This biofilm produced by the bacteria is capable of utilizing dissolved organic matter and other organic contaminants in the water through the process of biodegradation; these activities increased the operational life of the carbon bed by keeping the pore open for longer time (Seredyńska-Sobecka et al. 2006; Hijnen et al. 2010). The BAC process filter can efficiently remove the organic biodegradable compounds, ammonia, many trace-level organic contaminants, and synthetic organic compounds (Hijnen et al. 2010). However, there is limited data available regarding the use of BAC in the removal of BAP or other endocrine-disrupting compounds. Biologically activated carbon could be one of the potential processes if it is properly biostimulated with some BPAdegrading bacteria. The degradation of organic contaminants like BPA by bacteria due to the activity of some extracellular enzymes that were excreted by the bacteria can easily diffuse into the micropores of the $\mathrm{AC}$ and react with the absorbed materials.

\section{Conclusion}

The contamination of water sources by BPs is a ground reality of our society, and their negative impact has already been visible in human health. Even though there are numbers of available sources of exposure of BPAs, water is one of the many that every organism needs to be sustained. Methods on how to produce high-quality and BPA-free water for consumption and maintain a healthy life are a current research question. The conventional and advanced water production plants all apply physical and chemical means to remove unwanted chemicals and microorganisms; however, they need complex and high-cost infrastructure.

Our understanding of bacteria in drinking water is limited, as a majority of consumers still think that drinking water is sterile. However, studies are just beginning to uncover that microorganisms are ubiquitous during the process of drinking water production and distribution. Some of these bacteria have the remarkable capacity to degrade organic contaminants including BPs. The bacteria also grow as biofilms on pipe surfaces and could have a potential if applied in the biofiltration process. However, it is emphasized here that biostimulation of BPdegrading bacteria, within lignocellulosic activated carbon, into a commercial biofiltration system is in its preliminary stages and still needs extensive and planned experiment. Despite the problems related to bacterial metabolites such as some toxic compounds, these toxic compounds may be produced during degradation and transformation in purification processes; thus, technology seems to have many advantages. These advantages include the use of selected bacterial strains (this selected bacterial species might have fast BPA degraders), the potential to perform complex degradation processes, and the capacity to complete oxidative reductive processes. It seems that with the upgrading of the activated carbon beads' properties, this technology has a future potential in commercial biofiltration systems. However, it is very complicated to maintain the bacterial performance in the surface of activated carbon in open environmental systems, and hence, there is a need for optimization to cope with environmental factors (carbon source temperature, $\mathrm{pH}$ ). Otherwise, the state of the bacteria does not reflect the desired outcomes.

Acknowledgements The help rendered by Delfina C. Dominguez, Amy R. Nava, Qin Gao, Fernanda Lugo, Jonathan Blattner, Angela M. Encerrado Manriquez, and Luisa Castillo is thankfully acknowledged. The authors thank Jaime (Jd) Arturo Desantiago for the technical support.

Funding information This work was financially supported by the Department of Biotechnology, projects of the DBT Overseas Associateship in respect of the Northeastern Region (NER) through NER-Biotechnology Program Management Cell (NER-BPMC) (Grant No. BT/20/NE/2011), and Ministry of Science and Technology, Government of India.

\section{Compliance with ethical standards}

Conflict of interest The authors declare that they have no conflict of interest.

\section{References}

Ahmed MJ, Theydan SK (2014) Fluoroquinolones antibiotics adsorption onto microporous activated carbon from lignocellulosic biomass by microwave pyrolysis. J Taiwan Inst Chem Eng 45:219-226

Álvarez P, Blanco C, Granda M (2007) The adsorption of chromium (VI) from industrial wastewater by acid and base-activated lignocellulosic residues. J Hazard Mater 144:400-405

Apaydın-Varol E, Erülken Y (2015) A study on the porosity development for biomass based carbonaceous materials. J Taiwan Inst Chem Eng 54:37-44

Barnes DK, Galgani F, Thompson RC, Barlaz M (2009) Accumulation and fragmentation of plastic debris in global environments. Philos Trans R Soc Lond Ser B Biol Sci 364:1985-1998 
Belcher SM, Chen Y, Yan S, Wang HS (2012) Rapid estrogen receptormediated mechanisms determine the sexually dimorphic sensitivity of ventricular myocytes to $17 \beta$-estradiol and the environmental endocrine disruptor bisphenol A. Endocrinology 153(2):712-720

Beausoleil C, Emond C, Cravedi JP, Antignac JP, Applanat M, Appenzeller BMR, Beaudouin R, Belzunces LP, Canivenc-Lavier MC, Elefantl E, Eustache F, Habert R, Kolf-Clauw M, Le Magueresse-Battistoni B, Mhaouty-Kodja S, Minier C, Michel C (2018) Regulatory identification of BPA as an endocrine disruptor: Context and methodology. Mol Cell Endocrinol. https://doi.org/10. 1016/j.mce.2018.02.001

Berkner S, Streck G, Herrmann R (2004) Development and validation of a method for determination of trace levels of alkylphenols and bisphenol A in atmospheric samples. Chemosphere 54:575-584

Bolz U, Hagenmaier H, Komer W (2001) Phenolic xenoestrogens in surface water, sediments, and sewage sludge from BadenWurttemberg, south-west Germany. Environ Pollut 115:291-301

Boyd GR, Palmeri JM, Zhang S, Grimm DA (2004) Pharmaceuticals and personal care products (PPCPs) and endocrine disrupting chemicals (EDCs) in stormwater canals and Bayou St. John in New Orleans, Louisiana, USA. Sci Total Environ 33:137-148

Burkhardt MR, Re R, Vello RC, Smith SG, Zaugg SD (2005) Pressurized liquid extraction using water/isopropanol coupled with solid-phase extraction cleanup for industrial and anthropogenic waste-indicator compounds in sediment. Anal Chim Acta 534:89-100

Ceyhan AA, Șahin Ö, Baytar O, Saka C (2013) Surface and porous characterization of activated carbon prepared from pyrolysis of biomass by two-stage procedure at low activation temperature and it's the adsorption of iodine. J Anal Appl Pyrolysis 104:378-383

Chandy JP, Angles ML (2004) Factors influencing the development of biofilms under controlled conditions. The Cooperative Research Centre for Water Quality and Treatment - Research report No 20

Chayid MA, Ahmed MJ (2015) Amoxicillin adsorption on microwave prepared activated carbon from Arundo donax Linn: isotherms, kinetics, and thermodynamics studies. J Environ Chem Eng 3:1592-1601

Cohen Y (2001) Biofiltration - the treatment of fluids by microorganisms immobilized into the filter bedding material: a review. Bioresour Technol 77:257-274

Colin A, Bach C, Rosin C, Munoz J-F, Dauchy X (2014) Is drinking water a major route of human exposure to alkyl phenol and bisphenol contaminants in France? Arch Environ Contam Toxicol 66:86-99

European Food Safety Authority (EFSA), Parma, Italy (2010) Scientific Opinion on Bisphenol A: evaluation of a study investigating its neurodevelopmental toxicity, review of recent scientific literature on its toxicity and advice on the Danish risk assessment of Bisphenol A. EFSA J 8(9):1829 https://efsa.onlinelibrary.wiley. com/doi/pdf/10.2903/j.efsa.2010.1829

Fischer J, Kappelmeyer U, Kastner M, Schauer F, Heipieper HJ (2010) The degradation of bisphenol A by the newly isolated bacterium Cupriavidus basilensis JF1 can be enhanced by biostimulation with phenol. Int Biodeter Biodegr 64:324-330

Fu PQ, Kawamura K (2010) Ubiquity of bisphenol A in the atmosphere. Environ Pollut 158:3138-3143

Fukazawa H, Hoshino K, Shiozawa T, Matsushita H, Terao Y (2001) Identification and quantification of chlorinated bisphenol $\mathrm{A}$ in wastewater from wastepaper recycling plants. Chemosphere 44: 973-979

Gao Y, Zhang W, Yue Q, Gao B, Sun Y, Kong J (2014) Simple synthesis of hierarchical porous carbon from Enteromorpha prolifera by a self-template method for supercapacitor electrodes. J Power Sources 270:403-410

Golden SH, Robinson KA, Saldanha I, Anton B, Ladenson PW (2009) Prevalence and incidence of endocrine and metabolic disorders in the United States: a comprehensive review. J Clin Endocrinol Metab 94(6):1853-1878

Gonzalez-Casado A, Navas N, del Olmo M, Vilchez JL (1998) Determination of bisphenol $\mathrm{A}$ in water by micro liquid-liquid extraction followed by silylation and gas chromatography-mass spectrometry analysis. J Chromatogr Sci 36:565-569

Gurten II, Ozmak M, Yagmur E, Aktas Z (2012) Preparation and characterisation of activated carbon from waste tea using $\mathrm{K}_{2} \mathrm{CO}_{3}$. Biomass Bioenergy 37:73-81

Hadjittofi L, Prodromou M, Pashalidis I (2014) Activated biochar derived from cactus fibres - preparation, characterization and application on $\mathrm{Cu}$ (II) removal from aqueous solutions. Bioresour Technol 159: 460-464

Harley KG, Gunier RB, Kogut K, Johnson C, Bradman A, Calafat AM, Eskenazi B (2013) Prenatal and early childhood bisphenol A concentrations and behavior in school-aged children. Environ Res 126: $43-50$

Hashimoto S, Horiuchi A, Yoshimoto T, Nakao M, Omura H, Kato Y, Tanaka H, Kannan K, Giesy JP (2005) Horizontal and vertical distribution of estrogenic activities in sediments and waters from Tokyo Bay, Japan. Arch Environ Contam Toxicol 48:209-216

Heidari H, Sedighi M, Zamir SM, Shojaosada SA (2017) Bisphenol A degradation by Ralstonia eutropha in the absence and presence of phenol. Int Biodeterior Biodegr 119:37-42

Henno K, Pettis AA (1966) Blend of polycarbonate resin and alkenylaromatic resin. Dow Chemical Co, assignee. Patent US, 3239582 A. 08 Mar. Print

Heredia L, Bellés M, LLovet MI, Domingo JL, Linares V (2016) Behavioral effects in mice of postnatal exposure to low-doses of 137-cesium and bisphenol A. Toxicology 18:10-16

Hijnen WA, Suylen GM, Bahlman JA, BrouwerHanzens A, Medema GJ (2010) GAC adsorption filters as barriers for viruses, bacteria and protozoan (oo) cysts in water treatment. Wat Res 44(4):1224-1234

Ho S-M, Tang W-Y, de Frausto JB, Prins GS (2006) Developmental exposure to estradiol and bisphenol A increases susceptibility to prostate carcinogenesis and epigenetically regulates phosphodiesterase type 4 variant 4 . Cancer Res 66(11):5624e5632

$\mathrm{Hu}$ Z, Srinivasan MP, Ni Y (2001) Novel activation process for preparing highly microporous and mesoporous activated carbons. Carbon N Y 39:877-886

Huang YQ, Wong CKC, Zheng JS, Bouwman H, Barra R, Wahlström B, Neretin L, Wong MH (2012) Bisphenol A (BPA) in China: a review of sources, environmental levels, and potential human health impacts. Environ Int 42:91-99

Inagaki M, Tascon J (2006) Pore formation and control in carbon materials. In: Bandosz $\mathrm{T}$ (ed) Act. Carbon surfaces environ. Remediat. Elsevier Ltd, Philadelphia, pp 49-105

Jörg O, Schulte-Oehlmann U, Kloas W, Jagnytsch O, Lutz I, Kusk KO, Wollenberger L, Santos EM, Paull GC, Van Look KJW, Tyler CR (2009) A critical analysis of the biological impacts of plasticizers on wildlife. Phil Trans R Soc B 364:2047-2062. https://doi.org/10. 1098/rstb.2008.0242

Kamaraj M, Rajeshwari S, Venckatesh R (2014) Biodegradation of bisphenol A by the tolerant bacterial species isolated from coastal regions of Chennai, Tamil Nadu, India. Int Biodeter Biodegr 93: 216-222

Kang JH, Kondo F (2002) Bisphenol A degradation by bacteria isolated from river water. Arch Environ Contam Toxicol 43:265-269

Kang JH, Ri N, Kondo F (2004) Streptomyces sp. strain isolated from river water has high bisphenol A degradability. Lett Appl Microbiol 39:178-180

Kennedy Anthony M, Reinert AM, Knappe DRU, Ferrer I, Scott Summers R (2015) Full- and pilot-scale GAC adsorption of organic micropollutants. Water Res 68:238-248

Khim JS, Kannan K, Villeneuve DL, Koh CH, Giesy JP (1999) Characterization and distribution of trace organic contaminants in 
sediment from Masan Bay, Korea. 1. Instrumental analysis. Environ Sci Technol 33:4199-4205

Khim JS, Lee KT, Kannan K, Villeneuve DL, Giesy JP, Koh CH (2001) Trace organic contaminants in sediment and water from Ulsan Bay and vicinity, Korea. Arch Environ Contac Toxicol 40:141-150

Kiran S, Giri BS, Sahi A, Geed SR, Kureel MK, Singh S, Dubey SK, Rai BN, Kumar S, Upadhyay SN, Singh RS (2017) Biofiltration of xylene using wood charcoal as the biofilter media under transient and high loading conditions. Bioresource Technology 242:351-358

Krimm H, Schnell H, Bottenbruch L (1962) Thermoplastic aromatic polycarbonates and their manufacture. Bayer Ag, assignee. Patent US 3028365 A. 03 Apr. Print

Kumar D, Thakur MK (2017) Anxiety like behavior due to perinatal exposure to bisphenol-A is associated with decrease in excitatory to inhibitory synaptic density of male mouse brain. Toxicology 378 : $107-113$

Lang IA, Galloway TS, Scarlett A, Henley WE, Depledge M (2008) Association of urinary bisphenol A concentration with medical disorders and laboratory abnormalities in adults. JAMA 300:1303-1131

Lee C-C, Jiang L-Y, Kuo Y-L, Hsieh C-Y, Chen CS, Tien C-J (2013) The potential role of water quality parameters on occurrence of nonylphenol and bisphenol A and identification of their discharge sources in the river ecosystems. Chemosphere 91:904-911

Lee S, Liao C, Song G-J, Ra K, Kannan K, Moon HB (2015) Emission of bisphenol analogues including bisphenol $\mathrm{A}$ and bisphenol $\mathrm{F}$ from wastewater treatment plants in Korea. Chemosphere 119:1000-1006

Lei BL, Luo JP, Zhan JM, Huang SB, Liu C, Wang ZJ (2008) Distribution of nonylphenols and bisphenol-A in the sediments of Wenyuhe River. Environ Chem 27:314-317

Li D, Zhou Z, Qing D, He Y, Wu T, Miao M, Wang J, Weng X, Ferber JR, Herrinton LJ (2010) Occupational exposure to bisphenol-A (BPA) and the risk of Self-Reported Male Sexual Dysfunction. Hum Reprod 25(2):519-527

Liao C, Liu F, Kannan K (2012) Bisphenol S, a new bisphenol analogue, in paper products and currency bills and its association with bisphenol A residues. End Iron SciTechnol 46(12):6515-6522

Lin PH (2001) Study on the estrogenic active substances in the environment. Study report (EPA-90-E3S5-02-01) submitted to the Taiwan Environmental Protection Administration, Taipei, Taiwan

Lin Y, Zeng XG, Wu DS, Wang X, Qu WD (2006) Study on bisphenol A induced primary cultured mesencephalic neuronal cell injury by oxidative stress. J Hygiene Res 35:419-423

Liu R, Zhou JL, Wilding A (2004a) Simultaneous determination of endocrine disrupting phenolic compounds and steroids in water by solid-phase extraction-gas chromatography-mass spectrometry. J Chromatogr A 1022:179-189

Liu R, Zhou JL, Wilding A (2004b) Microwave-assisted extraction followed by gas chromatography-mass spectrometry for the determination of endocrine disrupting chemicals in river sediments. J Chromatogr A 1038:19-26

Liu B, Wang W, Wang N, Tong A(P)C (2014) Preparation of activated carbon with high surface area for high-capacity methane storage. J Energy Chem 23:662-668

Liu D, Zhang W, Lin H, Li Y, Lu H, Wang Y (2015) A green technology for the preparation of high capacitance rice husk-based activated carbon. J Clean Prod:1-9

Lobos JH, Leib TK, Su TM (1992) Biodegradation of bisphenol A and other bisphenols by a gram-negative aerobic bacterium. Appl Environ Microbiol 58:1823-1831

Mahamuni D, Shrinithivihahshini ND (2017) Need for regulatory policies in India, on the use of bisphenol A in food contact plastic containers. Curr Sci 113:861-868

Matsumura Y, Hosokawa C, Sasaki-Mori M, Akahira A, Fukunaga K, Ikeuchi T, Oshiman K, Tsuchido T (2009) Isolation and characterization of novel bisphenol-A-degrading bacteria from soils. Biocontrol Sci 14:161-169

Matsushima A et al. (2007) Structural evidence for endocrine disruptor bisphenol A binding to human nuclear receptor ERR $\gamma$. J Biochem 142(4): 517-524

Mita L, Grumiro L, Rossi S, Bianco C, Defez R, Gallo P, Mita DG, Diano N (2015) Bisphenol A removal by a Pseudomonas aeruginosa immobilized on granular activated carbon and operating in a fluidized bed reactor. J Hazard Mater 291:129-135

Moreno-Castilla C (2004) Adsorption of organic molecules from aqueous solutions on carbon materials

Nieto-Delgado C, Rangel-Mendez JR (2013) In situ transformation of agave bagasse into activated carbon by use of an environmental scanning electron microscope. Microporous Mesoporous Mater 167:249-253

Pei XR, Li Y, Long DX, Chen X, Gao LF, Chen XG (2003) In vitro study of bisphenol-A toxicity on the early embryo development of mice. Chin J Reprod Health 14:34-37

Qiu LL, Wang X, Zhang XH, Zhang Z, Gu J, Liu L et al (2013) Decreased androgen receptor expression may contribute to spermatogenesis failure in rats exposed to low concentration of bisphenol A. Toxicol Lett 219:116-124

Quesada I, Fuentes E, Viso-León MC, Soria B, Ripoll C, Nadal A (2002) Low doses of the endocrine disruptor bisphenol-A and the native hormone $17 \beta$-estradiol rapidly activate transcription factor CREB. FASEB J 16(12):1671-1673

Quinlivan PA, Li L, Knappe DRU (2005) Effects of activated carbon characteristics on the simultaneous adsorption of aqueous organic micropollutants and natural organic matter. Water Res 39(8):1663-1673

Quintelas C, Silva B, Figueiredo H, Tavares T (2010) Removal of organic compounds by a biofilm supported on GAC: modelling of batch and column data. Biodegradation 21(3):379-392

Ramírez M, Fernández M, Granada C, Le Borgne S, Gómez JM, Cantero D (2011) Biofiltration of reduced sulphur compounds and community analysis of sulphur-oxidizing bacteria. Bioresour Technol 102: 4047-4053. https://doi.org/10.1016/j.biortech.2010.12.018

Ramirez-Lopez EM, Corona-Hernandez J, Avelar-Gonzalez FJ, Omil F, Thalasso F (2010) Biofiltration of methanol in an organic biofilter using peanut shells as medium. Bioresour Technol 101:87-91

Rattier M, Reungoat J, Gernjak W, Keller J (2012) Organic micropollutant removal by biological activated carbon filtration: a review. Urban Water Security Research Alliance Technical Report ISSN 1836-5566 (Online) University of Queensland

Rochester JR, Bolden AL (2015) Bisphenol S and F: a systematic review and comparison of the hormonal activity of bisphenol A substitutes. Environ Health Prospect 10:643-650

Rodríguez-Reinoso F, Buschow KHJ, Robert WC, Merton CF, Bernard I, Edward JK, Subhash M, Roh H, Subramanya N, Zhao F, Yu C-P, Sandt J, Chu K-H (2009) Biodegradation potential of wastewater micropollutants by ammonia-oxidizing bacteria. Chemosphere 77(8):1084-1089

Rogers JA, Metz L, Yong VW (2013) Review: endocrine disrupting chemicals and immune responses: A focus on bisphenol-A and its potential mechanisms. Mol Immunol 53:421-430

Rosario-Ortiz Fernando L, Wert Eric C, Snyder Shane A (2010) Evaluation of UV/H2O2 treatment for the oxidation of pharmaceuticals in wastewater. Water Res 44(5):1440-1448

Saiyood S, Vangnai AS, Thiravetyan P, Inthorn D (2010) Bisphenol A removal by the Dracaena plant and the role of plant-associating bacteria. J Hazard Mater 178:777-785

Sakai K, Yamanaka H, Moriyoshi K, Ohmoto T, Ohe T (2007) Biodegradation of bisphenol A and related compounds by Sphingomonas sp. strain BP-7 isolated from seawater. Biosci Biotechnol Biochem 71:51-57 
Sasaki M, Maki J, Oshiman K, Matsumura Y, Tsuchido T (2005) Biodegradation of bisphenol A by cells and cell lysate from Sphingomonas sp. strain AO1. Biodegradation 16:449-459

Schröder E, Thomauske K, Weber C, Hornung A, Tumiatti V (2007) Experiments on the generation of activated carbon from biomass. $\mathrm{J}$ Anal Appl Pyrolysis 79:106-111

Selvaraj KK, Shanmugam G, Sampath S, JoakimLarsson DG, Ramaswamy BR (2014) GC-MS determination of bisphenol $\mathrm{A}$ and alkylphenol ethoxylates in river water from India and their ecotoxicological risk assessment. Ecotoxicol Environ Saf 99:13-20

Seredyńska-Sobecka B, Tomaszewska M, Morawski AW (2006) Removal of humic acids by the ozonation-biofiltration process. Desalination 198:265-273

Sha Y, Lou J, Bai S, Wu D, Liu B, Ling Y (2015) Facile preparation of nitrogen-doped porous carbon from waste tobacco by a simple pretreatment process and their application in electrochemical capacitor and $\mathrm{CO}_{2}$ capture. Mater Res Bull 64:327-332

Shao B, Han H, Tu X, Huang L (2007) Analysis of alkylphenol and bisphenol $\mathrm{A}$ in eggs and milk by matrix solid phase dispersion extraction and liquid chromatography withtandem mass spectrometry. J Chromatogr B Anal Technol Biomed Life Sci 850(1-2):412416

Sharma RP, Schuhmacher M, Kumar V (2018) The development of a pregnancy PBPK Model for Bisphenol A and its evaluation with the available biomonitoring data. Sci Total Environ 624:55-68

Simpson DR (2008) Biofilm processes in biologically active carbon water purification. Water Res 42(12):2839-2848

Stachel B, Ehrhorn U, Heemken OP, Lepom P, Reincke H, Sawal W et al (2003) Xenoestrogens in the River Elbe and its tributaries. Environ Pollut 124:497-507

Stachel B, Jantzen E, Knoth W, Kruger F, Lepom P, Oetken M et al (2005) The Elbe flood in August 2002-organic contaminants in sediment samples taken after the flood event. J Environ Sci Heal A 40:265-287

Stackelberg PE, Furlong ET, Meyer MT, Zaugg SD, Henderson AK, Reissman DB (2004) Persistence of pharmaceutical compounds and other organic wastewater contaminants in a conventional drinking-water-treatment plant. Sci Total Environ 329:99-113

Staples CA, Dorn PB, Klecka GM, O’Block ST, Harris LR (1998) A review of the environmental fate, effects, and exposures of bisphenol A. Chemosphere 36:2149-2173

Steinmetz R, Brown NG, Allen DL, Bigsby RM, BenJonathan N (1997) The environmental estrogen bisphenol A stimulates prolactin release in vitro and in vivo. Endocrinology 138(5): $1780-1786$

Stuart JD, Capulong CP, Launer KD, Pan X (2005) Analyses of phenolic endocrine disrupting chemicals in marine samples by both gas and liquid chromatography-mass spectrometry. J Chromatogr A 1079: 136-145

Telke A, Kalyani DC, Jadhav UU, Parshetti GK, Govindwar SP (2009) Purification and characterization of an extracellular laccase from a Pseudomonas sp. LBC1 and its application for the removal of bisphenol A. J Mol Catal B Enzym 61:252-260

Tsai W (2006) Human health risk on environmental exposure to Bisphenol-A: a review. J Environ Sci Health C 24:225-255 US EPA, 2016

USEPA (2010) U.S. Environmental Protection Agency, Bisphenol A action plan. Available at: 〈http://www.epa.gov/oppt/existingchemicals/ pubs/actionplans/bpa_action_plan.pdf $>$

Vandenberg LN, Maffini MV, Sonnenschein C, Rubin BS, Soto AM (2009) Bisphenol-A and the great divide: a review of controversies in the field of endocrine disruption. Endocr Rev 30:75-95 vom Saal FS, Hughes C (2005) An extensive new literature concerning low-dose effects of bisphenol A shows the need for a new risk assessment. Environ Health Perspect 113:926-933

vom Saal FS et al (1997) Prostate enlargement in mice due to fetal exposure to low doses of estradiol or diethylstilbestrol and opposite effects at high doses. Proc Natl Acad Sci 94(5): 2056-2061

Vukčević MM, Kalijadis AM, Vasiljević TM, Babić BM, Laušević ZV, Laušević MD (2015) Production of activated carbon derived from waste hemp (Cannabis sativa) fibers and its performance in pesticide adsorption. Microporous Mesoporous Mater 214:156-165

Wang XJ, Zhang YM, Li HS, Duan ZW, Cui JS (2005) Study of bisphenol A on reproductive and developmental toxicities in mice. Chin Occup Med 32:37-39

Wert EC, Rosario-Ortiz FL, Drury DD, Snyder SA (2007) Formation of oxidation byproducts from ozonation of wastewater. Water Res 41: $1481-1490$

Wilson NK, Chuang JC, Lye C (2001) Levels of persistent organic pollutants in several child day care centers. J Expo Anal Environ Epidemiol 11:449-458

Wozniak AL, Bulayeva NN, Watson CS (2005) Xenoestrogens at picomolar to nanomolar concentrations trigger membrane estrogen receptor- $\alpha$-mediated $\mathrm{Ca}^{2+}$ fluxes and prolactin release in GH3/B6 pituitary tumor cells. Environ Health Perspect 113:431-439

Wu M, Wang L, Xu G, Liu N, Tang L, Zheng J, Bu T, Lei B (2013) Seasonal and spatial distribution of 4-tert-octylphenol, 4nonylphenol and bisphenol A in the Huangpu River and its tributaries, Shanghai, China. Environ Monit Assess 185:3149-3161

Xie B, Liang SB, Tang Y, Mi WX, Xu Y (2009) Petrochemical wastewater odor treatment by biofiltration. Bioresour Technol 100:2204-2209

Xiong J, An T, Li G, Peng P (2017) Accelerated biodegradation of BPA in water-sediment microcosms with Bacillus sp. GZB and the associated bacterial community structure. Chemosphere 184:120-126. https://doi.org/10.1016/j.chemosphere

Xu Z, Qin N, Wang J, Tong H (2010) Formaldehyde biofiltration as affected by spider plant. Bioresour Technol 101:6930-6934

Xue Y, Wan, Kannan K (2016) Occurrence of bisphenols, bisphenol A diglycidyl ethers (BADGEs), and novolac glycidyl ethers (NOGEs) in indoor air from Albany, New York, USA, and its implications for inhalation exposure. Chemosphere 151:1-8

Yamanaka H, MoriyoshI K, Ohmoto T, Ohe T, Sakai K (2008) Efficient microbial degradation of bisphenol $\mathrm{A}$ in the presence of activated carbon. J Biosci Bioeng 105:157-160

Yamazaki E, Yamashita N, Taniyasu S, Lam J, Lam PK, Moon HB, Jeong Y, Kannan P, Achyuthan H, Munuswamy N, Kannan K (2015) Bisphenol $\mathrm{A}$ and other bisphenol analogues including BPS and BPF in surface water samples from Japan, China, Korea and India. Ecotoxicol Environ Saf 122:565-572

Yu X, Xue J, Yao H, Wu Q, Venkatesan AK, Halden RU, Kannan K (2015a) Occurrence and estrogenic potency of eight bisphenol analogues in sewage sludge from the U.S. EPA targeted national sewage sludge survey. J Hazard Mater 299:733-739

Yu X, Zhang K, Tian N, Qin A, Liao L, Du R et al (2015b) Biomass carbon derived from sisal fiber as anode material for lithium-ion batteries. Mater Lett 142:193-196

Zhang C, Zeng G, Yuan L, Yu J, Li J, Huang G, Xi B, Liu H (2007) Aerobic degradation of bisphenol A by Achromobacter xylosoxidans strain B-16 isolated from compost leachate of municipal solid waste. Chemosphere 68:181-190

Zhang JH, Shi D, Jiang M, Hao QL, Zhou YK, Lu B (2005) Study on the DNA damage and repair effect of Bisphenol A in human embryo liver L-02 cell line. J Environ Occup Med 22:197-199 
Zhang Z, Wang L, Shao L (2010) Study on relationship between characteristics of DOC and removal performance by BAC filter. 4th International Conference on Bioinformatics and Biomedical Engineering (iCBBE) Location: Chengdu, PEOPLES R CHINA Date: JUN 18-20, 2010

Zhang T, Sun H, Kannan K (2013) Blood and urinary bisphenol A concentrations in children, adults, and pregnant women from China: partitioning between blood and urine and maternal and fetal cord blood. Environ Sci Technol 47:4686-4694

Zhu Y-t, Yang C-x, Luo B-B, Zhou K, Liu S-l (2017) Efficiency of dairy strains of lactic acid bacteria to bind bisphenol $\mathrm{A}$ in phosphate buffer saline. Food Control 73:1203-1209 